\title{
PREPARATION OF NEW OPTICALLY ACTIVE AND THERMALLY STABLE POLY(AMIDE-IMIDE) CONTAINING BICYCLO SEGMENT AND ETHER GROUP IN THE MAIN CHAIN BY DIRECT POLYCONDENSATION IN TWO DIFFERENT MEDIA
}

\author{
KHALIL FAGHIHI *, MEISAM SHABANIAN ${ }^{2}$ \\ ${ }^{I}$ Polymer Research Laboratory, Department of Chemistry, Faculty of Science, Islamic Azad University, Arak Branch, Arak, Iran. \\ ${ }^{2}$ Islamic Azad University, Arak Branch, Young Researchers Club, Araky, Iran
}

(Received: May 31, 2010 - Accepted: November 15, 2010)

\begin{abstract}
A new series of optically active and thermally stable poly(amide-imide)s (PAIs) with good inherent viscosities based on bicyclo diacids and etheric diamine in the main chain were synthesized from the direct polycondensation reaction of $N, N^{\prime}$-(bicyclo[2,2,2]oct-7-ene-tetracarboxylic)-bis- $L$-amino acids 3a-g with 1,2-Bis[4-aminophenoxy] ethane 7 by direct polycondensatios with two different media such as direct polycondensation in a medium consisting of $N$-methyl-2pyrrolidone (NMP)/triphenyl phosphite (TPP)/calcium chloride $\left(\mathrm{CaCl}_{2}\right) /$ pyridine (Py) and direct polycondensation in a tosyl chloride (TsCl)/pyridine (Py)/N,Ndimethylformamide (DMF) system. Also 3a-g were synthesized by the condensation reaction of bicyclo[2,2,2]oct-7-ene-2,3,5,6-tetracarboxylic dianhydride $\mathbf{1}$ with two equimolars of various amino acids such as $L$-alanine $\mathbf{2 a}, L$-valine $\mathbf{2 b}, L$-leucine $\mathbf{2 c}, L$-isoleucine $\mathbf{2 d}, L$-phenylalanine $\mathbf{2 e}, L$-2-aminobutyric acid $\mathbf{2 f}$ and $L$-histidine $\mathbf{2 g}$ in an acetic acid solution.

The polymerization reactions produced a series of thermally stable and optically active organosoluble PAIs. The resulting polymers were fully characterized by means of FT-IR and ${ }^{1} \mathrm{H}$-NMR spectroscopy, elemental analyses, inherent viscosity, specific rotation, solubility tests and differential scanning calorimeter (DSC). Also thermal properties of the PAIs 8a-g were investigated using thermal gravimetric analysis (TGA) and derivative of thermaogravimetric (DTG) analysis.
\end{abstract}

Key word: Thermal properties; Optically active; Organosoluble; Poly(amide-imide)

\section{INTRODUCTION}

High-performance polymeric materials are currently receiving considerable attention for their potential applications in advanced technologies demands. Aromatic polyimides are well known high-performance polymers that show excellent thermal, mechanical and electrical properties. ${ }^{1,2}$ However, applications may be rather limited due to their high softening or melting temperatures and their insoluble nature in most organic solvents. ${ }^{3}$

Modification of high performance materials by increasing the solubility and lowering the transition temperatures while maintaining thermal stability are of particular interest. Copolycondensation is one of the possible ways for medication of polymer properties. Thus, for the processing of polyimides many copolyimides, such as poly(amide-imide)s, poly(ester-imide)s, and other copolymers have been prepared..$^{4-9}$ Aromatic polymers that contain aryl ether linkages and other flexible units such as $-\mathrm{NHCO}-$ and $-\mathrm{SO}_{2}$ - generally have lower glasstransition temperatures, greater chain flexibility and tractability in compare to their corresponding polymers these groups in the chain. ${ }^{10-12}$ The lower glass transition temperatures and also improved solubility are attributed to the flexible linkages that provide a polymer chain with a lower energy of internal rotation. ${ }^{13}$

Nature uses chirality as one of the key structural factors to perform a series of complicated functionalities, such as molecular recognition and catalytic activities. ${ }^{14}$ Synthesis and characterization of optically active polymers have been a challenging theme in the field of polymer synthesis in recent years for their important applications of optically active polymers as catalysts for asymmetric synthesis and as chiral stationary phases (CSP) for the direct optical resolution of enantiomers. ${ }^{15-17}$ Optically active polymers can be obtained by polymerization of optically active monomers or by stereo selective polymerization of racemic or prochiral monomers using optically active catalysts. ${ }^{18,19}$

In this article, a series of new optically active and thermally stable organosoluble PAIs 8a-g containing bicycle and ether moiety were synthesized by the direct polycondensation reactions of seven chiral $N, N^{\prime}$-(bicyclo[2,2,2] oct7-ene-tetracarboxylic)-bis- $L$-amino acids 3a-g with 1,2-Bis[4-aminophenoxy] ethane 7 by two different media such as direct polycondensation in a medium consisting of $N$-methyl-2-pyrrolidone (NMP)/triphenyl phosphite (TPP)/ calcium chloride $\left(\mathrm{CaCl}_{2}\right)$ /pyridine $(\mathrm{Py})$ and direct polycondensation in a tosyl chloride (TsCl)/pyridine (Py)/N,N-dimethylformamide (DMF) system.

\section{EXPERIMENTAL}

\section{Materials}

Bicyclo[2,2,2] oct-7-ene-2,3,5,6-tetracarboxylic dianhydride 1 (from Aldrich), L-alanine 2a, L-valine 2b, L-leucine 2c, L-isoleucine 2d, L-phenyl alanine $2 \mathbf{e}$ and L-2-aminobutyric acid $\mathbf{2 f}$, L-histidine $\mathbf{2 g}$, 1,2-dibromoethane 4, p-nitrophenol 5 and tosyl chloride ( $\mathrm{TsCl}$; from Merck) were used without previous purification. Solvent: N-methyl-2-pyrrolidone (NMP; from Fluka), pyridine (from Acros), triphenyl phosphite (TPP; from Merck) and N,Ndimethylformamide (DMF; from Merck) were used as received. Commercially available calcium chloride $\left(\mathrm{CaCl}_{2}\right.$; from Merck) was dried under vacuum at $150^{\circ} \mathrm{C}$ for 6 hrs.

\section{Techniques}

${ }^{1} \mathrm{H}-\mathrm{NMR}$ and ${ }^{13} \mathrm{C}-\mathrm{NMR}$ spectra were recorded on a Bruker $300 \mathrm{MHz}$ instrument (Germany). Fourier transform infrared (FT-IR) spectra were recorded on Galaxy series FT-IR 5000 spectrophotometer (England). Spectra of solid were performed by using $\mathrm{KBr}$ pellets. Vibration transition frequencies were reported in wave number $\left(\mathrm{cm}^{-1}\right)$. Band intensities were assigned as weak (w), medium (m), shoulder (sh), strong (s) and broad (br). Inherent viscosities were measured by a standard procedure by using a Technico Regd Trad Mark Viscometer. Specific Rotations were measured by an A-Kruss polarimeter. Thermal Gravimetric Analysis (TGA and DTG) data for polymers were taken on a Mettler TA4000 System under $\mathrm{N}_{2}$ atmosphere at rate of $10^{\circ} \mathrm{C} / \mathrm{min}$ and differential scanning calorimetry (DSC) was conducted with a DSC Metller 110 (Switzerland) at a heating rate of $10^{\circ} \mathrm{Cmin}^{-1}$ in a nitrogen atmosphere. The temperature range was from 25 to $350^{\circ} \mathrm{C}$. The glass transition temperature $(\mathrm{Tg})$ of PAI was recorded based on the second scanning. Elemental analyses were performed by Vario EL equipment in Arak University.

\section{Monomer synthesis}

Synthesis of $N, N^{\prime}$-(bicyclo[2,2,2] oct-7-ene-tetracarboxylic)-bis- $L$-amino acids 3a-g

$1 \mathrm{~g}(4.03 \mathrm{mmol})$ of bicyclo[2,2,2]oct-7-ene-2,3,5,6-tetracarboxylic dianhydride $\mathbf{1}, 8.06 \mathrm{mmol}$ of $L$-amino acids $\mathbf{2 a - g}, 50 \mathrm{~mL}$ of acetic acid and a stirring bar were placed into a $250-\mathrm{mL}$ round-bottomed flask. The mixture was stirred at room temperature for overnight and refluxed for $4 \mathrm{hrs}$. The solvent was removed under reduced pressure, and the residue was dissolved in 100 $\mathrm{mL}$ of cold water, then the solution was decanted and $5 \mathrm{~mL}$ of concentrated $\mathrm{HCl}$ was added. A white precipitate was formed, filtered off, and dried to give compounds $N, N^{\prime}$-(bicyclo[2,2,2]oct-7-ene-tetracarboxylic)-bis- $L$-amino acids 3a-g. ${ }^{8}$

1,2-bis[4,4'-aminophenoxy]ethane 7 
1,2-bis[4-aminophenoxy]ethane 7 was synthesized according to the pervious work. ${ }^{20}$

\section{Polymer synthesis}

Poly(amide-imide)s 8a-g were synthesized by two different methods that as an example the preparation of PAI 8a explains in the following.

Method A: Direct polycondensation in a medium consisting of $N$-methyl2-pyrrolidone (NMP)/triphenyl phosphite (TPP)/calcium chloride $\left(\mathrm{CaCl}_{2}\right)$ ) pyridine $(P y)$

$0.107 \mathrm{~g}(0.275 \mathrm{mmol})$ of $N, N^{\prime}$-(bicyclo[2,2,2]oct-7-ene-tetracarboxylic)bis- $L$-alanine 3a, $0.067 \mathrm{~g}(0.275 \mathrm{mmol})$ of 1,2 -Bis [4-aminophenoxy] ethane 7, $0.1 \mathrm{~g}(0.9 \mathrm{mmol})$ of calcium chloride, $0.84 \mathrm{~mL},(3.00 \mathrm{mmol})$ of triphenyl phosphite, $0.1 \mathrm{~mL}$ of pyridine and $1.5 \mathrm{~mL} \mathrm{~N}$-methyl-2-pyrrolidone (NMP) were placed into a $25-\mathrm{mL}$ round-bottomed flask, which was fitted with a stirring bar. The reaction mixture was heated under reflux at $120^{\circ} \mathrm{C}$ for $8 \mathrm{hrs}$. Then, the reaction mixture was poured into $50 \mathrm{~mL}$ of methanol and the precipitated polymer was collected by filtration and washed thoroughly with hot methanol and dried at $60^{\circ} \mathrm{C}$ for $12 \mathrm{hrs}$ under vacuum to leave $0.151 \mathrm{~g} \mathrm{(92 \% )} \mathrm{pale} \mathrm{yellow}$ solid polymer $\mathbf{8 a}$.

Method B: Direct Polycondensation in a Tosyl Chloride (TsCl)/Pyridine $(P y) / N, N$-Dimethylformamide (DMF) System

A solution of $0.1 \mathrm{~mL}$ pyridine, $0.078 \mathrm{~g}(0.411 \mathrm{mmol})$ of $\mathrm{TsCl}$ after $30 \mathrm{~min}$ stirring at room temperature was treated with $0.1 \mathrm{~mL},(1.36 \mathrm{mmol})$ of DMF for additional $30 \mathrm{~min}$. The reaction mixture was added dropwise to a solution 0.053 $\mathrm{g}(0.137 \mathrm{mmol})$ of diacid $\mathbf{3 a}$ in $0.1 \mathrm{~mL}$ of pyridine. The mixture was maintained at room temperature for $30 \mathrm{~min}$, and then to this mixture, a solution $0.033 \mathrm{~g}$ $(0.137 \mathrm{mmol})$ of 1,2-Bis[4-aminophenoxy] thane $7 \mathrm{in} 0.1 \mathrm{~mL}$ of Pyridine was added dropwise and the whole solution was stirred at room temperature for 30 min and at $110^{\circ} \mathrm{C}$ for $2 \mathrm{hrs}$. As the reaction proceeded, the solution became viscous, then was precipitated in $30 \mathrm{~mL}$ of methanol and filtered off, dried under vacuum to leave $0.121 \mathrm{~g}(74 \%)$ brown solid polymer $8 \mathbf{a}$.

\section{RESULTS AND DISCUSSION}

\section{Synthesis of monomers}

The asymmetric diacids 3a-g were synthesized by the condensation reaction of bicyclo[2,2,2] oct-7-ene-2,3,5,6-tetracarboxylic dianhydride 1 with two equimolars of $L$-alanine $\mathbf{2 a}, L$-valine $\mathbf{2 b}, L$-leucine $\mathbf{2 c}, L$-isoleucine $\mathbf{2 d}$, $L$-phenyl alanine $2 \mathbf{e}, L$-2-aminobutyric acid $\mathbf{2 f}$ and $L$-histidine $\mathbf{2 g}$ in an acetic acid solution (scheme 1). The yields and some physical properties of these compounds are shown in Table 1.
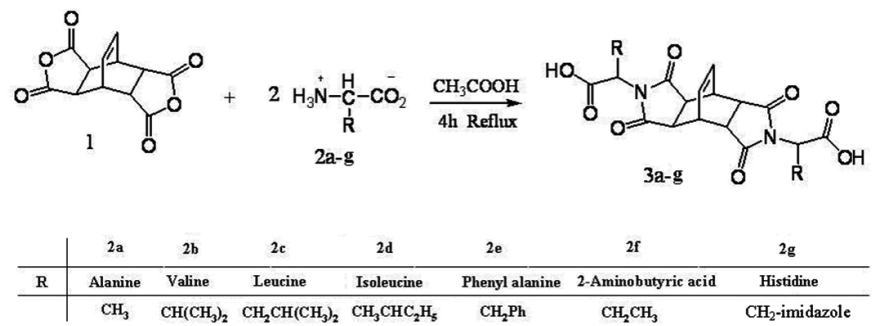

Scheme 1: Preparation of diacids 3a-g

Table 1 Some physical properties of chiral diacid derivatives 3a-g

\begin{tabular}{|c|c|c|c|c|c|}
\hline Entry & $\begin{array}{c}\text { Amino acid } \\
\text { compound }\end{array}$ & $\mathrm{R}$ & $\mathrm{Mp}\left({ }^{\circ} \mathrm{C}\right)$ & Yield(\%) & {$[\text { á }]_{\mathrm{D}}^{\mathbf{z}} \mathbf{~ a}$} \\
\hline 3a & L-Alanine & $\mathrm{CH}_{3}$ & $249-250$ & 92 & +155.7 \\
\hline $\mathbf{3 b}$ & L-Valine & $\left(\mathrm{CH}_{3}\right)_{2} \mathrm{CH}$ & $318-320$ & 93 & +138.4 \\
\hline $\mathbf{3 c}$ & L-Leucine & $\left(\mathrm{CH}_{3}\right)_{2} \mathrm{CHCH}_{2}$ & $289-290$ & 94 & +146.8 \\
\hline 3d & L-Isoleucine & $\left(\mathrm{C}_{2} \mathrm{H}_{5}\right)\left(\mathrm{CH}_{3}\right) \mathrm{CH}$ & $293-295$ & 92 & +156.2 \\
\hline 3e & $\begin{array}{c}\text { L-Phenyl } \\
\text { alanine }\end{array}$ & $\mathrm{PhCH}_{2}$ & $247-248$ & 91 & +160.2 \\
\hline 3f & $\begin{array}{c}\text { L-2- } \\
\text { Aminobutyric } \\
\text { acid }\end{array}$ & $\mathrm{CH}_{3} \mathrm{CH}_{2}$ & $251-253$ & 93 & +130.2 \\
\hline $\mathbf{3 g}$ & L-histidine & $\mathrm{CH}_{2}$-imidazole & $310-312$ & 85 & +128.4 \\
\hline
\end{tabular}

${ }^{\text {a }}$ Measured at a concentration of $0.5 \mathrm{~g} / \mathrm{dL}$ in DMF at $25^{\circ} \mathrm{C}$.
The chemical structure and purity of the optically active diacids $\mathbf{3 a - g}$ were proved by using elemental analysis, FT-IR, ${ }^{1} \mathrm{H}-\mathrm{NMR}$ and ${ }^{13} \mathrm{C}-\mathrm{NMR}$ spectroscopic techniques and these data shown in Table 2.

Table $2{ }^{1} \mathrm{H}$-NMR, ${ }^{13} \mathrm{C}-\mathrm{NMR}$, FT-IR spectra and elemental analyses data of diacid derivatives 3a-g.

\begin{tabular}{|c|c|}
\hline Diimide-diacid & Spectral data \\
\hline & ${ }^{1} \mathrm{H}-\mathrm{NMR}\left(\mathrm{DMSO}-\mathrm{d}_{\mathrm{G}}, \delta \mathrm{ppm}\right): 12.87-12.93(\mathrm{~s}, \mathrm{br}, 2 \mathrm{H})$, \\
& $5.95-5.98(\mathrm{t}, 2 \mathrm{H}), 4.50-4.57(\mathrm{q}, 1 \mathrm{H}, \mathrm{J}=7 \mathrm{~Hz}), 3.37(\mathrm{~s}$, \\
& $2 \mathrm{H}), 3.16-3.25(\mathrm{~m}, 4 \mathrm{H}), 1.23-1.25(\mathrm{~d}, 6 \mathrm{H}){ }^{13} \mathrm{C}-\mathrm{NMR}$ \\
& $\left(\mathrm{DMSO}-\mathrm{d}_{6}, \delta \mathrm{ppm}\right): 176.82,170.61,130.64,47.55$, \\
& $42.47,33.89,14.49 . \mathrm{FT}-\mathrm{IR}\left(\mathrm{KBr}, \mathrm{cm}^{-1}\right): 2561-3100$ \\
3a & $(\mathrm{m}, \mathrm{sh}, \mathrm{br}), 1770(\mathrm{w}), 1705(\mathrm{~s}, \mathrm{br}), 1628(\mathrm{w}), 1467(\mathrm{w})$, \\
& $1396(\mathrm{~m}), 1309(\mathrm{~m}), 1207(\mathrm{~m}), 1126(\mathrm{w}), 976(\mathrm{w}), 675$ \\
& $(\mathrm{w}), 611(\mathrm{w})$. Elemental analysis: calcd. for $\mathrm{C}_{18} \mathrm{H}_{18} \mathrm{~N}_{2} \mathrm{O}_{8}$ \\
& $: \mathrm{C}, 55.39 ; \mathrm{H}, 4.65 ; \mathrm{N}, 7.18 ;$ found: $\mathrm{C}, 54.45 ; \mathrm{H}, 4.56 ;$ \\
& $\mathrm{N}, 7.11$.
\end{tabular}

${ }^{1} \mathrm{H}-\mathrm{NMR}$ (DMSO-d, 6 ppm): 12.88 (s, br, 2H), 5.99$6.09(\mathrm{~m}, 2 \mathrm{H}), 4.12-4.15(\mathrm{~d}, 2 \mathrm{H}, \mathrm{J}=9 \mathrm{~Hz}), 3.45(\mathrm{D} \mathrm{O}$ exchange, $\mathrm{s}, 2 \mathrm{H}), 3.18-3.25\left(\mathrm{D}_{2} \mathrm{O}\right.$ exchange, $\left.\mathrm{t}, 4 \mathrm{H}\right)$, 2.32-2.39 (m, 2H), 0.92-0.94 (d, 6H, J=6 Hz), 0.66$0.68(\mathrm{~d}, 6 \mathrm{H}, \mathrm{J}=6 \mathrm{~Hz}) .{ }^{13} \mathrm{C}-\mathrm{NMR}\left(\mathrm{DMSO}-\mathrm{d}_{6}, \delta \mathrm{ppm}\right.$ ):

3b 177.23, 169.55, 131.51, 57.70, 42.61, 33.84, 27.96, 21.28, 19.60. FT-IR $\left(\mathrm{KBr}, \mathrm{cm}^{-1}\right): 2500-3400(\mathrm{~m}, \mathrm{br})$, 1709-1770 (s, br), 1390 (s), 1199 (s, sh), 1068 (m), $775(\mathrm{w}), 700(\mathrm{~m}), 603(\mathrm{w})$. Elemental analysis: calcd. for $\mathrm{C}_{22} \mathrm{H}_{26} \mathrm{~N}_{2} \mathrm{O}_{8}$ : C, 59.19; $\mathrm{H}, 5.87 ; \mathrm{N}, 6.27$; found: $\mathrm{C}$, $58.98 ; \mathrm{H}, 5.87 ; \mathrm{N}, 6.25$.

${ }^{1} \mathrm{H}-\mathrm{NMR}$ (DMSO-d,$\left.\delta \mathrm{ppm}\right): 12.70$ (s, br, 2H), 5.93$6.01(\mathrm{~m}, 2 \mathrm{H}), 4.44-4.49(\mathrm{dd}, 2 \mathrm{H}, \mathrm{J}=6,3 \mathrm{~Hz}), 3.40$ $(\mathrm{s}, 2 \mathrm{H}), 3.21-3.30(\mathrm{~m}, 4 \mathrm{H}), 1.85(\mathrm{~m}, 2 \mathrm{H}), 1.65(\mathrm{~m}$, $2 \mathrm{H}), 1.25(\mathrm{~m}, \mathrm{br}, 2 \mathrm{H}), 0.75-0.81(\mathrm{q}, 12 \mathrm{H}) .{ }^{13} \mathrm{C}-\mathrm{NMR}$ (DMSO-d,$\delta$ ppm): 177.09, 170.46, 130.97, 50.73,

$3 c$ 42.44, 36.62, 33.80, 24.60, 23.47, 21.14. FT-IR ( KBr, $\mathrm{cm}^{-1}$ ): 2500-3200 (m, br), $1770(\mathrm{w}), 1710$ (s, br), 1628 (w), $1460(\mathrm{~m}), 1380(\mathrm{~m}), 1309(\mathrm{~m}), 1207(\mathrm{w}), 1126(\mathrm{w})$, $976(w), 670(w), 600(w)$. Elemental analysis: calcd. for $\mathrm{C}_{24} \mathrm{H}_{30} \mathrm{~N}_{2} \mathrm{O}_{8}: \mathrm{C}, 60.75 ; \mathrm{H}, 6.37 ; \mathrm{N}, 5.90$; found: $\mathrm{C}$, $60.25 ; \mathrm{H}, 6.22 ; \mathrm{N}, 5.88$.

${ }^{1} \mathrm{H}-\mathrm{NMR}$ (DMSO-d,$\delta$ ppm): 12.8 (s, br, 2H), 5.97$6.03(\mathrm{~m}, 2 \mathrm{H}), 4.18-4.21(\mathrm{~d}, 2 \mathrm{H}, \mathrm{J}=9 \mathrm{~Hz}), 3.22-3.30$ $(\mathrm{m}, 6 \mathrm{H}), 2.14-2.15(\mathrm{~d}, 2 \mathrm{H}, \mathrm{J}=3 \mathrm{~Hz}), 1.30-1.37(\mathrm{~m}$, $2 \mathrm{H}), 0.89-0.91(\mathrm{~d}, 6 \mathrm{H}, \mathrm{J}=6 \mathrm{~Hz}), 0.71-0.74(\mathrm{t}, 6 \mathrm{H})$. ${ }^{13} \mathrm{C}-\mathrm{NMR}$ (DMSO-d,$\delta \mathrm{ppm}$ ): 177.59, 169.66, 131.27, $57.03,42.40,33.67,25.24,16.90,10.87$. FT-IR (KBr, $\mathrm{cm}^{-1}$ ): 2500-3400 (m, br), $1772(\mathrm{w}), 1744$ (s, sh), 1709 (s, sh), 1390 (s), 1232 (w), 1225 (m), 806 (w), 717 (w), 599 (w), 314 (m). Elemental analysis: calcd. for $\mathrm{C}_{24} \mathrm{H}_{30} \mathrm{~N}_{2} \mathrm{O}_{8}: \mathrm{C}, 60.75 ; \mathrm{H}, 6.37 ; \mathrm{N}, 5.90$; found: $\mathrm{C}$, $60.45 ; \mathrm{H}, 6.21 ; \mathrm{N}, 5.91$.

${ }^{1} \mathrm{H}$ NMR (DMSO-d,$\delta$ ppm): 13.15 (s, br, 2H), 7.217.23 (q, 6H), 7.02-7.03 (t, 4H), 4.85-4.91 (dd, br, $2 \mathrm{H}$, $\mathrm{J}=6,6 \mathrm{~Hz}), 3.25-3.31(\mathrm{dd}, 2 \mathrm{H}, \mathrm{J}=12,3 \mathrm{~Hz}), 3.10-3.12$ (d, $2 \mathrm{H}, \mathrm{J}=6 \mathrm{~Hz}), 3.01-3.05$ (d, 4H, J=12 Hz), 2.92-2.94 $(\mathrm{d}, 2 \mathrm{H}, \mathrm{J}=6 \mathrm{~Hz}) \cdot{ }^{13} \mathrm{C}$ NMR (DMSO-d $6, \delta \mathrm{ppm}$ ): 176.69 ,

$3 \mathbf{e}$ 169.94, $132.02,129.32,128.53,126.98,53.07,42.24$ $42.11,33.45,33.24$. FT-IR $\left(\mathrm{KBr}, \mathrm{cm}^{-1}\right): 2600-3500(\mathrm{~m}$, br), 1776 (w), 1703 (s, br), 1498 (w), 1398 (w), 1394 (s), $1234(\mathrm{~m}, \mathrm{br}), 1174(\mathrm{~s}), 933(\mathrm{w}), 698(\mathrm{~m})$. Elemental analysis: calcd. for $\mathrm{C}_{30} \mathrm{H}_{26} \mathrm{~N}_{2} \mathrm{O}_{8}: \mathrm{C}, 66.41 ; \mathrm{H}, 4.83 ; \mathrm{N}$, 5.16; found: $\mathrm{C}, 66.41 ; \mathrm{H}, 4.82 ; \mathrm{N}, 5.10$. 


\begin{tabular}{|c|c|}
\hline $\mathbf{3 f}$ & $\begin{array}{l}{ }^{1} \mathrm{H} \text { NMR }\left(\mathrm{DMSO}-\mathrm{d}_{6}, \delta \mathrm{ppm}\right): 12.95(\mathrm{~s}, \mathrm{br}, 2 \mathrm{H}), 6.01- \\
6.10(\mathrm{~m}, 2 \mathrm{H}), 4.33-4.38(\mathrm{dd}, 2 \mathrm{H}, \mathrm{J}=6,3 \mathrm{~Hz}), 3.43 \\
\left(\mathrm{D}_{2} \mathrm{O}-\mathrm{exchang}, \mathrm{s}, \mathrm{br}, 2 \mathrm{H}\right), 3.20-3.27\left(\mathrm{D}_{2} \mathrm{O}-\text {-exchang, } \mathrm{q},\right. \\
4 \mathrm{H}), 1.91-1.93(\mathrm{~m}, 2 \mathrm{H}), 1.79-1.81(\mathrm{~m}, 2 \mathrm{H}), 0.66-0.71 \\
(\mathrm{t}, 6 \mathrm{H}){ }^{13} \mathrm{C} \mathrm{NMR}\left(\mathrm{DMSO}-\mathrm{d}_{6}, \delta \mathrm{ppm}\right): 177.14,170.19, \\
131.06,56.50,42.41,33.79,21.23,11.06 . \text { FT-IR }(\mathrm{KBr} \text {, } \\
\left.\mathrm{cm}^{-1}\right): 2650-3400(\mathrm{~m}, \mathrm{br}), 1776(\mathrm{~s}, \mathrm{br}), 1498(\mathrm{w}), 1390 \\
(\mathrm{~s}), 1224(\mathrm{~m}, \mathrm{br}), 1170(\mathrm{~s}), 933(\mathrm{w}), 698(\mathrm{~m}) \text {. Elemental } \\
\text { analysis: calcd. for } \mathrm{C}_{20} \mathrm{H}_{22} \mathrm{~N}_{2} \mathrm{O}_{8}: \mathrm{C}, 57.41 ; \mathrm{H}, 5.30 ; \mathrm{N} \text {, } \\
6.70 \text {; found: } \mathrm{C}, 57.34 ; \mathrm{H}, 5.29 ; \mathrm{N}, 6.70 \text {. }\end{array}$ \\
\hline $3 g$ & 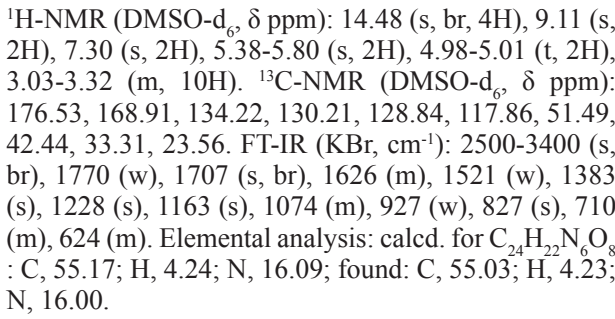 \\
\hline
\end{tabular}

The FT-IR spectra of all $N, N^{\prime}$-(bicyclo[2,2,2]oct-7-ene-tetracarboxylic)bis- $L$-amino acids 3a-g showed absorption around 2500 and $3400 \mathrm{~cm}^{-1}$, which was assigned to the $\mathrm{COOH}$ groups. Peaks appearing at around 1700$1770 \mathrm{~cm}^{-1}$ (acid $\mathrm{C}=\mathrm{O}$ and symmetric imide stretching), 1390 and $700 \mathrm{~cm}^{-1}$ (imide characteristic ring vibration) confirmed the presence of imide ring and carboxylic groups in these compounds.

As an example, the ${ }^{1} \mathrm{H}-\mathrm{NMR}$ spectrum of diacid $\mathbf{3} \mathbf{f}$ is showed in Figure 1. The protons $\mathrm{H}(\mathrm{a})$ relevant to $\mathrm{O}-\mathrm{H}$ carboxylic groups appeared at $12.95 \mathrm{ppm}$. Peak in 4.33-4.38 ppm as a doublet of doublet which were assigned to the $\mathrm{H}(\mathrm{c})$ protons, which is a chiral center, peaks between $0.66-0.71 \mathrm{ppm}$ were assigned to aliphatic $\mathrm{CH}_{3}(\mathrm{~g})$, peak in $1.79-1.93 \mathrm{ppm}$ were assigned to $\mathrm{H}(\mathrm{f})$. Protons relevant to olefin bicyclo ring appeared at 6.01-6.10 ppm, H(b). Peaks between 3.20-3.43 ppm were assigned to $\mathrm{H}(\mathrm{e})(4 \mathrm{H})$ and $\mathrm{H}(\mathrm{d})(2 \mathrm{H})$, that appeared in $\mathrm{D}_{2} \mathrm{O}$ exchange ${ }^{1} \mathrm{H}-\mathrm{NMR}$ spectrum. Also the ${ }^{13} \mathrm{C}-\mathrm{NMR}$ spectrum of diacid $\mathbf{3 f}$ showed 8 signals, including $\mathrm{C}(\mathrm{b})$ and $\mathrm{C}(\mathrm{a})$ in carboxylic acids and carbonyl imide rings, and $\mathrm{C}(\mathrm{c})$ in carbon atoms olefin in bicyclo (Figure 2). These peaks in ${ }^{1} \mathrm{H}-\mathrm{NMR}$ and ${ }^{13} \mathrm{C}$-NMR spectra along with elemental analyses data confirmed the proposed structure of compound $\mathbf{3 f}$.

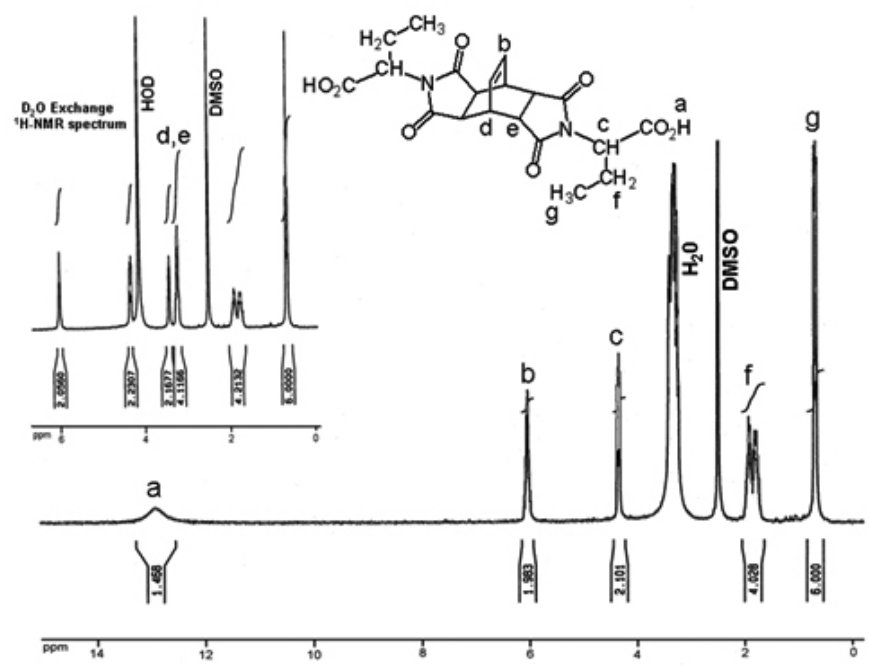

Fig. 1: ${ }^{1} \mathrm{H}-\mathrm{NMR}$ spectrum of diacid $\mathbf{3 f}$

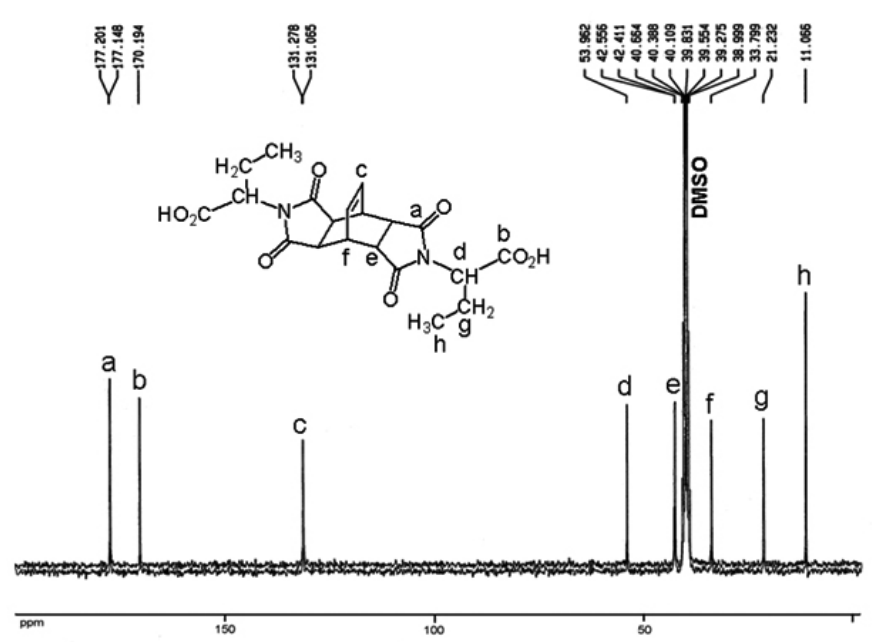

Fig. 2: ${ }^{13} \mathrm{C}-\mathrm{NMR}$ spectrum of diacid $\mathbf{3 f}$

1,2-bis[4-aminophenoxy] ethane 7 was synthesized according this method: At first 1,2-bis[4,4'-nitrophenoxy] ethane $\mathbf{6}$ was prepared from the reaction of two equimolars p-nitrophenol 5 and one equimolar 1,2-dibromo ethane 4 . Then dinitro compound $\mathbf{6}$ was reduced by using $10 \% \mathrm{Pd}-\mathrm{C}$, ethanol and hydrazine monohydrate (Scheme 1).

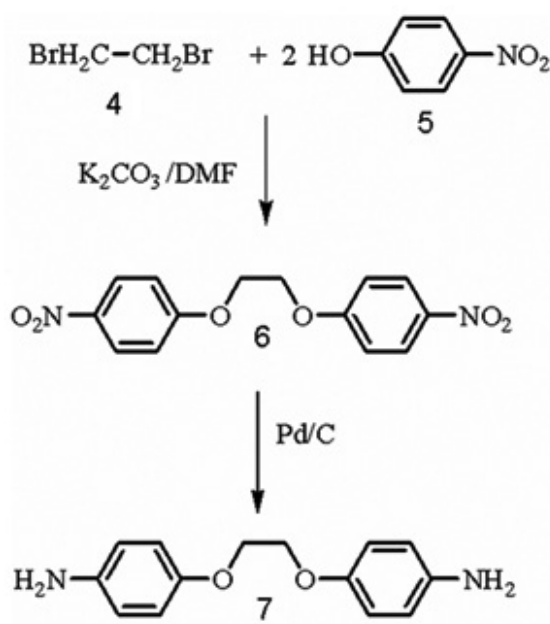

Scheme 2: Synthesis of diamine 7

The chemical structure and purity of dinitro compound 6 were proved with elemental analysis, ${ }^{1} \mathrm{H}-\mathrm{NMR}$ and FT-IR spectroscopy and diamine compound 7 were proved with elemental analysis, FT-IR, ${ }^{1} \mathrm{H}-\mathrm{NMR}$, and ${ }^{13} \mathrm{C}-\mathrm{NMR}$ spectroscopy.

The measured results in elemental analyses of these compounds were closely corresponded to the calculated ones, demonstrating that the expected compounds were obtained. The FT-IR spectrum of diamine 7 showed two peaks at 3406 and $3327 \mathrm{~cm}^{-1}$, which were assigned to the $\mathrm{NH}_{2}$ groups.

6.66-6.69 (d, 4H, J=9 Hz), 6.48-6.51 (d, 4H, J=9 Hz), $4.63(\mathrm{~s}, 4 \mathrm{H}), 4.07$ (s, 4H) ppm. ${ }^{13} \mathrm{C}-\mathrm{NMR}\left(300 \mathrm{MHz}, \mathrm{DMSO}-\mathrm{d}_{6}\right): \delta ; 150.0,143.0,115.8,115.3$, 67.3 ppm. Elemental

${ }^{1} \mathrm{H}-\mathrm{NMR}$ spectrum of diamine 7 showed peaks as a doublet of doublet at 6.66-6.69 ppm and 6.48-6.51 ppm were assigned to the $H(a)$ and $H(b)$ related to aromatic protons, and a singlet peak at $4.07 \mathrm{ppm}$ which was assigned to the $\mathrm{H}(\mathrm{d})$ protons of the $\mathrm{NH}_{2}$ groups in this compound (Fig. 3). 


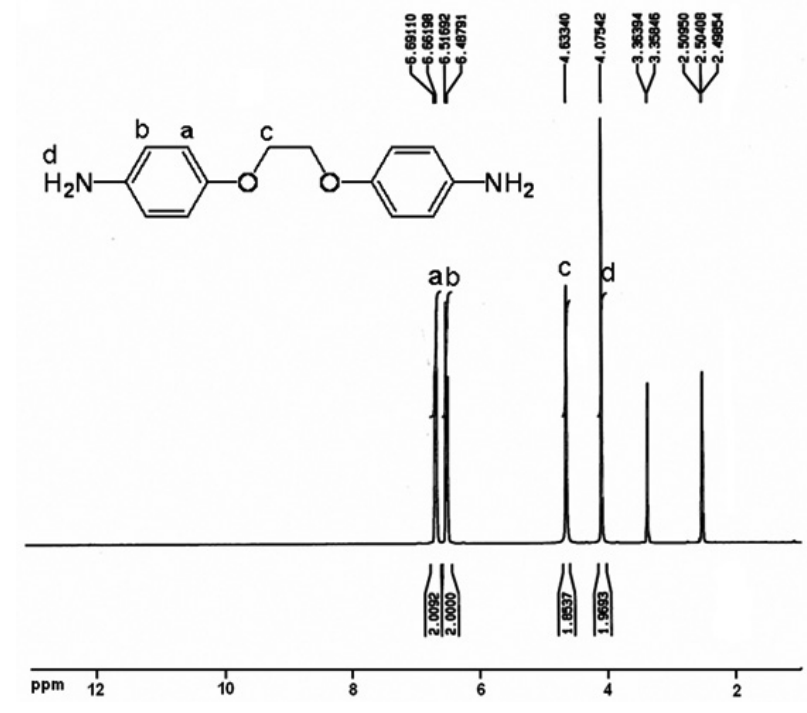

Fig. 3: ${ }^{1} \mathrm{H}-\mathrm{NMR}$ spectrum of diamine 4

\section{Polymer synthesis}

The direct polycondensation of a dicarboxylic acid and diamine is one of the well-known methods for PAI synthesis. In this article, we synthesized PAIs 8a-g containing dibenzalacetone moiety by the direct polycondensation reactions of seven chiral $N, N^{\prime}$-(bicyclo[2,2,2] oct-7-ene-tetracarboxylic)-bis- $L$ amino acids 3a-g with 1,2-bis[4,4'-aminophenoxy]ethane 7 in two different media such as direct polycondensation in a medium consisting of $\mathrm{N}$-methyl2-pyrrolidone (NMP)/triphenyl phosphite (TPP)/calcium chloride $\left(\mathrm{CaCl}_{2}\right) /$ pyridine (Py) (method A, Scheme 3) and direct polycondensation in a tosyl chloride (TsCl)/pyridine (Py)/N,N-dimethylformamide (DMF) system (Media B, Scheme 3)
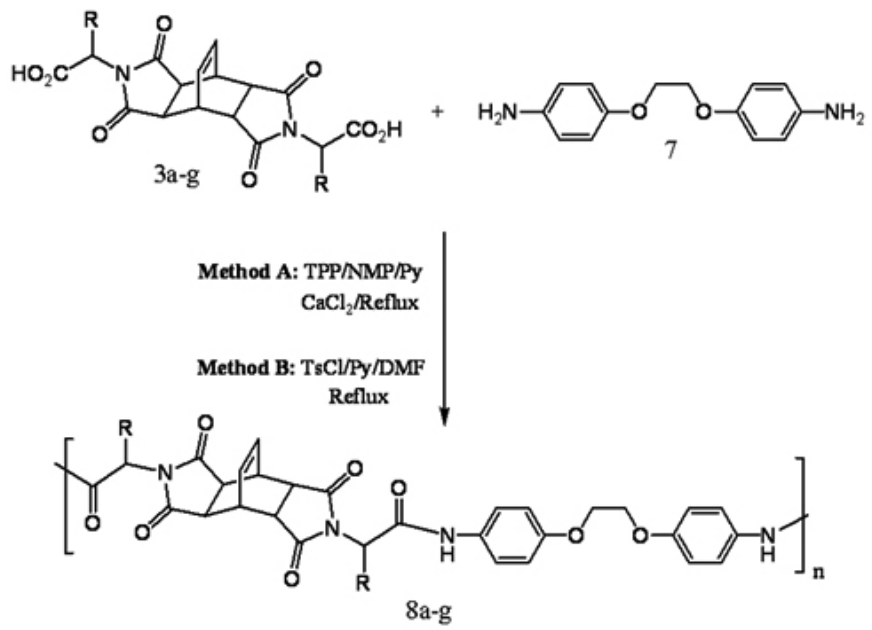

Scheme 3: Synthesis of PAIs 8a-g in two different media

In media $\mathrm{A}$ for direct polycondensation used TPP/Py/CaCl 2 as activating agent according to a typical procedure that was shown in Scheme 3. A triphenyl phosphite (TPP)-activated polycondensation (phosphorylation reaction) technique for the synthesis of polyamides was reported by Yamazaki et al. ${ }^{21}$

The syntheses and some physical properties of these new PAIs 8a-g are given in Table 3 . The entire polycondensation reaction readily proceeds in a homogeneous solution, tough and stringy precipitates formed when the viscous PAIs solution was obtained in good yields.

In method B for the direct polycondensation of diacids 3a-g and aromatic diamine 7, a Vilsmeier adduct was prepared by dissolving $\mathrm{TsCl}$ in a mixed solvent of Py and DMF. The polycondensation was carried out as the following way: $\mathrm{TsCl}$ was dissolved in Py and after a certain period of time (aging time); the solution was treated with DMF for $30 \mathrm{~min}$. The reaction mixture was added to a solution of diacid in Py. After 30 min, a solution of diamine in Py was added and the whole solution was maintained at room temperature, and then at refluxing temperature. ${ }^{22}$

The polymers with high inherent viscosities were obtained at $2 \mathrm{hrs}$ time. The syntheses and some physical properties of these new PAIs 8a-g are given in Table 4 . The entire polycondensation reaction readily proceeds in a homogeneous solution, tough and stringy precipitates formed when the viscous PAIs solution was obtained in moderate yields. Although PAIs 8a-g obtained in a shorter period in media B, but these polymers obtained with higher inherent viscosities and good yields in media $\mathrm{A}$.

One of the main methods for synthesis of optically active polymers is incorporation of chiral segments in the monomer structure. In this work we used of chiral amino acid moieties for synthesis of chiral diacids 3a-g. Also Specific Rotations of the resulting polymers were measured at a concentration of $0.5 \mathrm{~g} / \mathrm{dL}$ in DMF at $25^{\circ} \mathrm{C}$ (Table 3 and 4).

Table 3 Yield and some physical properties PAIs 8a-g by media A.

\begin{tabular}{|c|c|c|c|c|c|}
\hline Diacid & Polymer & Yield(\%) & $\eta_{\text {inh }}(\mathrm{dL} / \mathrm{g})^{\mathrm{a}}$ & {$\left[{ }_{\mathrm{a}}\right]_{\mathrm{D}}^{\mathbf{z}}{ }^{\mathrm{a}}$} & Color $^{\mathrm{b}}$ \\
\hline $\mathbf{3 a}$ & $\mathbf{8 a}$ & 92 & 0.75 & +88 & $\mathrm{~W}$ \\
\hline $\mathbf{3 b}$ & $\mathbf{8 b}$ & 91 & 0.85 & +110 & $\mathrm{Y}$ \\
\hline $\mathbf{3 c}$ & $\mathbf{8 c}$ & 86 & 0.78 & +110 & $\mathrm{~W}$ \\
\hline $\mathbf{3 d}$ & $\mathbf{8 d}$ & 91 & 0.59 & +76 & $\mathrm{Y}$ \\
\hline $\mathbf{3 e}$ & $\mathbf{8 e}$ & 91 & 0.66 & +96 & $\mathrm{PY}$ \\
\hline $\mathbf{3 f}$ & $\mathbf{8 f}$ & 92 & 0.69 & +86 & $\mathrm{Y}$ \\
\hline $\mathbf{3 g}$ & $\mathbf{8 g}$ & 83 & 0.51 & +124 & $\mathrm{PY}$ \\
\hline
\end{tabular}

a, Measured at a concentration of $0.5 \mathrm{~g} / \mathrm{dL}$ in DMF at $25^{\circ} \mathrm{C}$.

', PY= Pale Yellow, Y=Yellow, W=White.

Table 4 Yield and some physical properties PAIs 8a-g by media B.

\begin{tabular}{|c|c|c|c|c|c|}
\hline Diacid & Polymer & Yield(\%) & $\eta_{\text {inh }}(\mathrm{dL} / \mathrm{g})^{\mathrm{a}}$ & & Color $^{\mathrm{b}}$ \\
\hline 3a & $\mathbf{8 a}$ & 74 & 0.50 & +102 & $\mathrm{~B}$ \\
\hline 3b & $\mathbf{8 b}$ & 77 & 0.38 & +92 & $\mathrm{Y}$ \\
\hline $\mathbf{3 c}$ & $\mathbf{8 c}$ & 83 & 0.46 & +68 & PB \\
\hline $\mathbf{3 d}$ & $\mathbf{8 d}$ & 75 & 0.28 & +56 & $\mathrm{Y}$ \\
\hline $\mathbf{3 e}$ & $\mathbf{8 e}$ & 81 & 0.61 & +110 & PY \\
\hline $\mathbf{3 f}$ & $\mathbf{8 f}$ & 68 & 0.54 & +58 & $\mathrm{~B}$ \\
\hline $\mathbf{3 g}$ & $\mathbf{8 g}$ & 82 & 0.30 & +62 & PB \\
\hline
\end{tabular}

a , Measured at a concentration of $0.5 \mathrm{~g} / \mathrm{dL}$ in DMF at $25^{\circ} \mathrm{C}$.

b, $\mathrm{B}=$ Brown, $\mathrm{PB}=$ Pale Brown, $\mathrm{PY}=$ Pale Yellow, $\mathrm{Y}=$ Yellow.

\section{Polymer properties}

The Spectroscopic results such as CHN, FT-IR and ${ }^{1} \mathrm{H}-\mathrm{NMR}$ data confirmed the structure of these polymers. The elemental analyses of the resulting PAIs 8a-g were in good agreement with the calculated values for the proposed structure (Table 5 ). 
Table 5 Elemental analysis results of PAIs 8a-g.

\begin{tabular}{|c|c|l|c|c|c|}
\hline Polymer & Formula & & $\mathrm{C} \%$ & $\mathrm{H} \%$ & $\mathrm{~N} \%$ \\
\hline $\mathbf{8 a}$ & $\mathrm{C}_{32} \mathrm{H}_{30} \mathrm{~N}_{4} \mathrm{O}_{8}$ & Calcd. & 64.21 & 5.05 & 9.36 \\
\hline & $(598.21)_{n}$ & Found & 63.64 & 4.98 & 9.18 \\
\hline $\mathbf{8 b}$ & $\mathrm{C}_{36} \mathrm{H}_{38} \mathrm{~N}_{4} \mathrm{O}_{8}$ & Calcd. & 66.04 & 5.85 & 8.56 \\
\hline & $(654.71)_{n}$ & Found & 63.54 & 5.79 & 8.22 \\
\hline $\mathbf{8 c}$ & $\mathrm{C}_{38} \mathrm{H}_{42} \mathrm{~N}_{4} \mathrm{O}_{8}$ & Calcd. & 66.85 & 6.20 & 8.21 \\
\hline & $(682.76)_{n}$ & Found & 66.11 & 6.21 & 8.04 \\
\hline $\mathbf{8 d}$ & $\mathrm{C}_{38} \mathrm{H}_{42} \mathrm{~N}_{4} \mathrm{O}_{8}$ & Calcd. & 66.85 & 6.20 & 8.21 \\
\hline & $(682.76)_{n}$ & Found & 66.08 & 6.18 & 7.98 \\
\hline $\mathbf{8 e}$ & $\mathrm{C}_{44} \mathrm{H}_{38} \mathrm{~N}_{4} \mathrm{O}_{8}$ & Calcd. & 70.39 & 5.10 & 7.46 \\
\hline & $(750.79)_{n}$ & Found & 70.02 & 5.06 & 7.27 \\
\hline $\mathbf{8 f}$ & $\mathrm{C}_{34} \mathrm{H}_{34} \mathrm{~N}_{4} \mathrm{O}_{8}$ & Calcd. & 65.17 & 5.47 & 8.94 \\
\hline & $(626.66)_{n}$ & Found & 64.89 & 5.39 & 8.80 \\
\hline $\mathbf{8 g}$ & $\mathrm{C}_{38} \mathrm{H}_{34} \mathrm{~N}_{8} \mathrm{O}_{8}$ & Calcd. & 62.46 & 4.69 & 15.33 \\
\hline & $(730.25)_{n}$ & Found & 61.98 & 4.62 & 14.98 \\
\hline
\end{tabular}

The representative FT-IR spectrum of PAI 8f was shown in Figure 4. The polymer exhibited characteristic absorption bands at $1772 \mathrm{~cm}^{-1}$ for the imide ring (asymmetric $\mathrm{C}=\mathrm{O}$ stretching vibration), $1709 \mathrm{~cm}^{-1}$ (symmetric $\mathrm{C}=\mathrm{O}$ stretching and amide stretching vibration) in the main chain, $1386 \mathrm{~cm}^{-1}(\mathrm{C}-\mathrm{N}$ stretching vibration). The absorption bands of amide groups appeared at 3335 $\mathrm{cm}^{-1}$ (N-H stretching). FT-IR characterizations of all PAIs are given in Table 6.

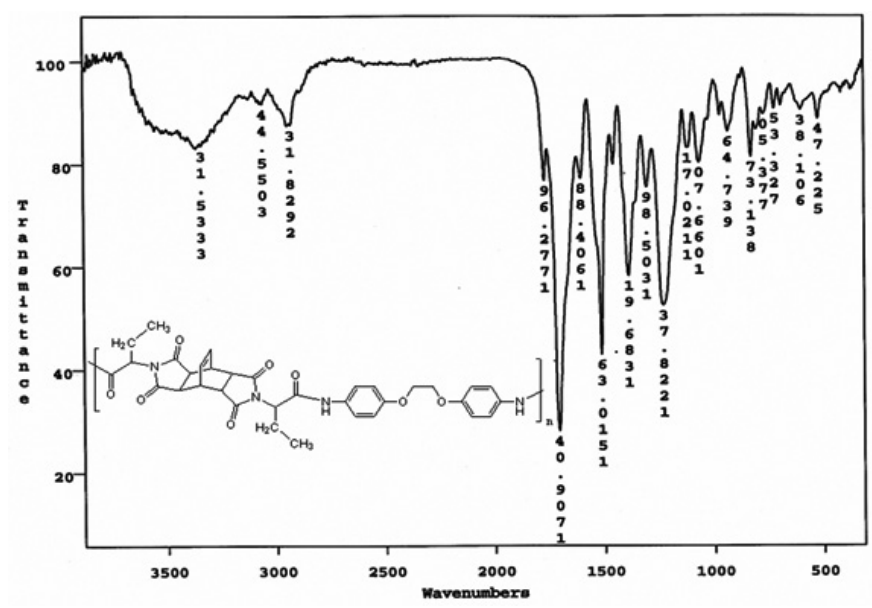

Fig. 4: FT-IR spectrum of PAI $8 \mathrm{f}$
Table 6 FT-IR characterization of PAIs 8a-g.

\begin{tabular}{|c|c|}
\hline Polymer & Spectral data $\left(v, \mathrm{~cm}^{-1}\right)$ \\
\hline $8 a$ & $\begin{array}{l}3269(\mathrm{w}), 2915(\mathrm{w}), 1774(\mathrm{w}), 1709(\mathrm{~s}), 1605(\mathrm{~m}), \\
1518(\mathrm{~m}), 1380(\mathrm{~m}), 1219(\mathrm{~m}), 1158(\mathrm{~m}), 1065(\mathrm{w}), \\
969(\mathrm{w}), 830(\mathrm{w}), 725(\mathrm{w}) .\end{array}$ \\
\hline $8 \mathbf{b}$ & $\begin{array}{l}3246(\mathrm{~m}), 2926(\mathrm{~m}), 1776(\mathrm{w}), 1710(\mathrm{~s}, \mathrm{br}), 1605(\mathrm{~s}), \\
1516(\mathrm{~s}), 1383(\mathrm{~s}), 1235(\mathrm{~s}), 1178(\mathrm{~m}), 1087(\mathrm{w}), 981 \\
(\mathrm{~m}), 830(\mathrm{~m}), 725(\mathrm{w}), 704(\mathrm{w}) .\end{array}$ \\
\hline $8 c$ & $\begin{array}{l}3245(\mathrm{w}), 2915(\mathrm{w}), 1776(\mathrm{w}), 1712(\mathrm{~s}), 1602(\mathrm{~m}), \\
1518(\mathrm{~m}), 1383(\mathrm{~m}), 1219(\mathrm{~m}), 1177(\mathrm{~m}), 1065(\mathrm{w}), \\
929(\mathrm{w}), 832(\mathrm{w}), 725(\mathrm{w}) .\end{array}$ \\
\hline $8 d$ & $\begin{array}{l}3252(\mathrm{w},), 2918(\mathrm{w}), 1774(\mathrm{w}), 1709(\mathrm{~s}), 1605(\mathrm{~m}), \\
1516(\mathrm{~m}), 1382(\mathrm{~m}), 1248(\mathrm{~m}), 1115(\mathrm{~m}), 1080(\mathrm{~s}), \\
983(\mathrm{w}), 837(\mathrm{w}), 725(\mathrm{w}) .\end{array}$ \\
\hline $8 e$ & $\begin{array}{l}3244(\mathrm{w}), 2928(\mathrm{~m}), 1776(\mathrm{w}), 1712(\mathrm{~s}), 1605(\mathrm{~m}), \\
1516(\mathrm{~m}), 1386(\mathrm{~m}), 1250(\mathrm{~m}), 1111(\mathrm{~m}), 1082(\mathrm{~m}), \\
983(\mathrm{w}), 837(\mathrm{w}), 729(\mathrm{w}) .\end{array}$ \\
\hline $8 f$ & $\begin{array}{l}3238(\mathrm{w}), 3055(\mathrm{w}), 2928(\mathrm{w}), 1772(\mathrm{w}), 1709(\mathrm{~s}), \\
1604(\mathrm{w}), 1510(\mathrm{~s}), 1386(\mathrm{~m}), 1305(\mathrm{w}), 1228(\mathrm{~s}, \mathrm{br}), \\
1120(\mathrm{w}), 1066(\mathrm{w}), 831(\mathrm{w}), 723(\mathrm{w}) .\end{array}$ \\
\hline $8 g$ & $\begin{array}{l}3243(\mathrm{w}, \mathrm{br}), 2918(\mathrm{~m}, \mathrm{br}), 1774(\mathrm{w}), 1710(\mathrm{~s}, \mathrm{br}), \\
1610(\mathrm{~m}), 1510(\mathrm{~m}), 1383(\mathrm{~m}), 1251(\mathrm{~m}), 1112(\mathrm{~m}), \\
1082(\mathrm{~s}), 983(\mathrm{w}), 837(\mathrm{w}), 725(\mathrm{w}) .\end{array}$ \\
\hline
\end{tabular}

Figure 5 displays ${ }^{1} \mathrm{H}-\mathrm{NMR}$ spectrum of PAI 8a that the aromatic protons related to diamine appeared in the region of 6.70-6.78 and 7.24-7.40 ppm and the peak in the region of $9.52 \mathrm{ppm}$ is assigned for $\mathrm{N}-\mathrm{H}$ of amide groups in the main chain of polymer. Decaying peak related to carboxylic acid protons and appearing peaks related to amide groups and aromatic protons of diamine in the polymer chain, confirmed the proposed structure of PAI 8a.

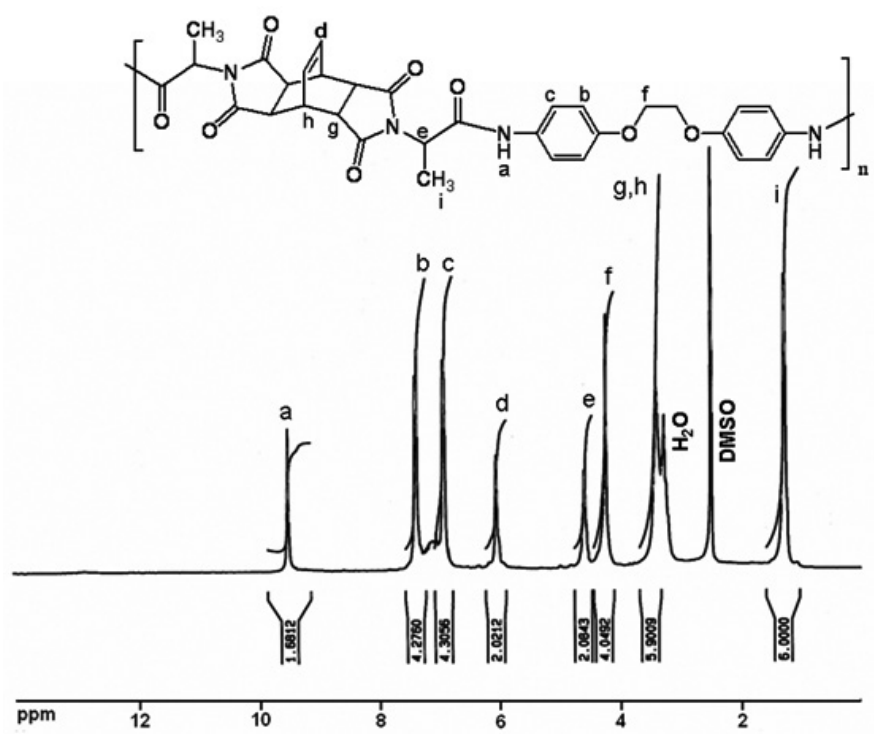

Fig. 5: ${ }^{1} \mathrm{H}-\mathrm{NMR}$ spectrum of PAI 8a

Solubility of the PAIs

One of the main objectives of this study was producing modified poly(amideimide)s with improved solubility. By the incorporation of monomers with ether and bicyclo moiety these polymers are expected to have higher solubility. The solubility of PAIs 8a-g was investigated as $0.01 \mathrm{~g}$ of polymeric sample in $2 \mathrm{~mL}$ of solvent. Remarkably, all of these PAIs were easily soluble at room temperature in aprotic polar solvents such as $N$-methyl-2-pyrrolidinone (NMP), $N, N$-dimethylacetamide (DMAc), $N, N$-dimethylformamide (DMF) and insoluble in solvents such as acetone, chloroform, ethanol and methanol. 


\section{Thermal properties}

TGA and derivative of thermaogravimetric (DTGA) analysis at a rate of $10^{\circ} \mathrm{Cmin}^{-1}$ in a nitrogen atmosphere were utilized to examine the thermal decomposition of these PAIs, and the obtained results are summarized in Table 7. Figure 6 show TGA results of all the PAIs.

The thermal stability of the polymers was studied on the basis of 5 and $10 \%$ weight losses ( $\mathrm{T}_{5}$ and $\mathrm{T}_{10}$, respectively) of the polymers and the residue at $600^{\circ} \mathrm{C}$ (char yield). The results revealed that the PAIs were thermally stable up to $320^{\circ} \mathrm{C}$. TGA data showed that the resulting polymers were good thermally stable. Also the DSC analyses for the polymers showed T between 175 and $215^{\circ} \mathrm{C}$ respectability (Table 7). Thermal stability and $\mathrm{T}$ value of the polymers $\mathbf{8 e}$ and $\mathbf{8 g}$ with aromatic rings were higher than the other polymers, because these polymers has a rigid aromatic structure in the side chain.

Table 7 Thermal behavior of all the PAIs.

\begin{tabular}{|ccccc|}
\hline Polymer & $\mathrm{T}_{\mathrm{g}}{ }_{\mathrm{a}}$ & $\mathrm{T}_{5}\left({ }^{\circ} \mathrm{C}\right)^{\mathrm{b}}$ & $\mathrm{T}_{10}\left({ }^{\circ} \mathrm{C}\right)^{\mathrm{b}}$ & Char yield $^{\mathrm{c}}$ \\
\hline $\mathbf{8 a}$ & 200 & 330 & 370 & 44.5 \\
\hline $\mathbf{8 b}$ & 185 & 320 & 340 & 43.62 \\
\hline $\mathbf{8 c}$ & 175 & 275 & 360 & 42.52 \\
\hline $\mathbf{8 d}$ & 185 & 220 & 310 & 43.21 \\
\hline $\mathbf{8 e}$ & 210 & 330 & 380 & 51.83 \\
\hline $\mathbf{8 f}$ & 195 & 270 & 375 & 38.25 \\
\hline $\mathbf{8 g}$ & 215 & 260 & 370 & 47.91 \\
\hline
\end{tabular}

${ }^{\text {a }}$ Glass transition temperature was recorded at a heating rate of $10^{\circ} \mathrm{Cmin}^{-1}$ in a nitrogen atmosphere.

${ }^{b}$ Temperature at which $5 \%$ or $10 \%$ weight loss was recorded in TGA analysis at a heating rate of $10{ }^{\circ} \mathrm{C} / \mathrm{min}$ under $\mathrm{N}_{2}$.

${ }^{c}$ Weight percentage of material left after TGA analysis at a maximum temperature of $600{ }^{\circ} \mathrm{C}$ under $\mathrm{N}_{2}$.

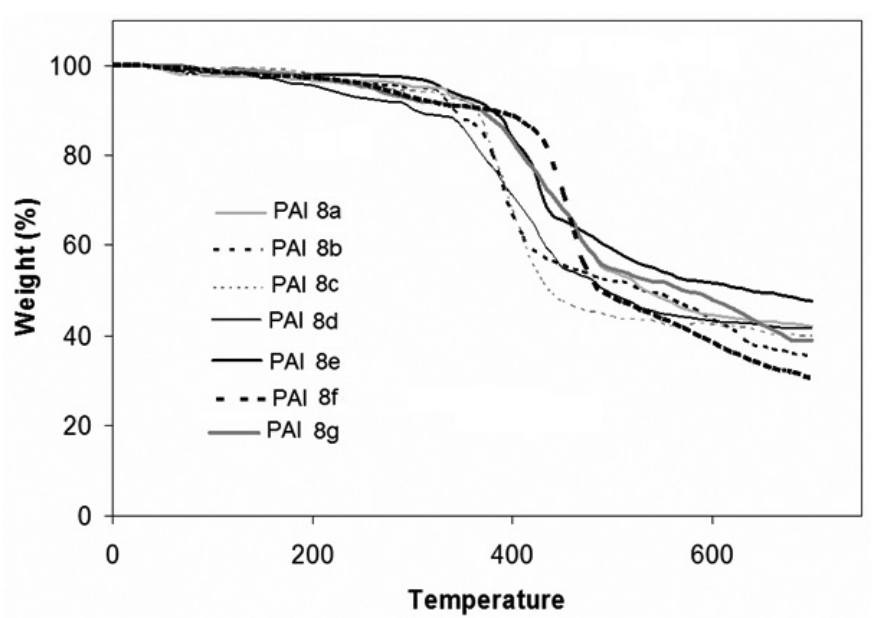

Fig. 6: TGA curves of all the PAIs

\section{CONCLUSIONS}

A series of new thermally stable and optically active organosoluble PAIs 8a-g containing containing bicyclo and ether groups moiety were synthesized by the direct polycondensation reactions of seven chiral diacids 3a-g with diamine 7 by two different methods. By introducing ether and bicyclo moiety into the polymer backbone the rigid conformation of the chains is modified increasing the solubility in polar aprotic solvents. Because the resulting polymers contained optically pure $L$-amino acid moieties, they showed optical rotations and were optically active. The presented results also clearly demonstrate that incorporating the imide group into the polymer main chain as well as combination of the wholly aromatic backbone and several functional groups remarkably enhanced the thermal stability of the new polymers. Potential applications of amino acid based polymers include chiral stationary phases for the resolution of enantiomers in chromatographic techniques, and biomaterials.

\section{REFERENCES}

1. Ghosh, M.K.; Mittal, K.L. Polyimides: Fundamentals and Applications. Marcel Dekker: New York (1996).

2. Ghosh, A.; Banerjee, S. Polym. Adv. Technol., 19, 1486, (2008).

3. Cassidy, P.E. Thermally Stable Polymers. Marcel Dekker: New York (1980).

4. Saxena, A.; Rao, V.L.; Prabhakaran, P.V.; Ninan, K.N. Eur. Polym. J., 39, 401, (2003).

5. Liaw, D.J.; Liaw, B.Y.; Hsu, P.N.; Hwang, C.Y. Chem. Mater., 13, 1811, (2001).

6. Mallakpour, S.; Meratian, S. High. Perform. Polym., 20, 3, (2008).

7. Faghihi, Kh.; Mozaffari, Z. J. Appl. Polym. Sci., 108, 1152, (2008).

8. Faghihi, Kh.; Hajibeygi, M.; Shabanian, M. Macromol. Res. 17, 739, (2009).

9. Faghihi, Kh.; Naghavi, H. J. Appl. Polym. Sci., 96, 1776, (2004)

10. Zhang, Q.; Li, S.; Li, W.; Zhang, S. Polymer, 48, 6246, (2007).

11. Zhang, Q.; Chen, G.; Zhang, S. Polymer, 48, 2250, (2007).

12. Bottino, F.A.; Pasquale, G.D.; Scalia, L.; Pollicino, A. Polymer, 42, 3323, (2001).

13. Gutch, P.K.; Banerjee, S.; Jaiswal, D.K. J. Appl. Polym. Sci., 89, 691, (2003).

14. Voet, D.; Voet, J.G.; Pratt, C.W. Fundamentals of Biochemistry. Wiley: New York (1999).

15. Mallakpour, S.; Zamanlou M.R. J. Appl. Polym. Sci., 91, 3281, (2004).

16. Liaw, D.J.; Chang, F.C.; Liu, J.H.; Wang, K.L.; Faghihi, Kh.; Huang, S.H.; Lee, K.R.; Lai, J.Y. Polym. Degrad. Stabil., 92, 323, (2007).

17. Yeganeh, H.; Tamami, B.; Ghazi, I. Eur. Polym. J., 38, 2179, (2002).

18. Faghihi, Kh. J. Appl. Polym. Sci., 109, 74, (2008).

19. Faghihi, Kh.; Shabanian, M.; Hajibeygi, M. Macromol. Res., 17, 912, (2009).

20. Eastmond, G.C., Paprotny, J. Polymer, 43, 3455, (2002).

21. Yamazaki, N.; Matsumoto, M.; Higashi, F. J. Polym. Sci. Part A: Polym. Chem., 13, 1373, (1975).

22. Mallakpour, S., Kolahdoozan, M. J. Appl. Polym. Sci., 104, 1248, (2007). 